\title{
PENGEMBANGAN INSTRUMEN PENILAIAN TWO-TIER MULTIPLE CHOICE QUESTION UNTUK MENGUKUR KETERAMPILAN PROSES SAINS SISWA PADA TEMA MATA SEBAGAI ALAT OPTIK
}

\author{
Dhika Rizqi Damayanti ${ }^{1}$, Sri Yamtinah ${ }^{2}$, dan Suryadi Budi Utomo ${ }^{3}$ \\ ${ }^{1}$ Progam Magister Pendidikan Sains FKIP Universitas Sebelas Maret \\ Surakarta, 57126, Indonesia \\ dhikarizqi0704@gmail.com \\ ${ }^{2}$ Progam Magister Pendidikan Sains FKIP Universitas Sebelas Maret \\ Surakarta, 57126, Indonesia \\ jengtina_sp@yahoo.com \\ ${ }^{3}$ Progam Magister Pendidikan Sains FKIP Universitas Sebelas Maret \\ Surakarta, 57126, Indonesia \\ sbukim98@yahoo.com
}

\begin{abstract}
Abstrak
Penelitian ini bertujuan mengetahui: 1) tahapan pengembangan two-tier multiple choice question, 2) kelayakan two-tier multiple choice question untuk mengukur keterampilan proses sains, 3) penggunaan profil siswa untuk mengukur keterampilan proses sains. Penelitian menggunakan prosedur Borg dan Gall yang direduksi menjadi 9 tahapan: 1) pendahuluan, 2) perencanaan, 3) pengembangan rancangan awal produk, 4) uji coba awal, 5) revisi produk uji coba awal, 6) uji coba lapangan, 7) revisi produk uji coba lapangan, 8) uji coba operasional, 9) revisi produk akhir. Penelitian dilakukan di SMPN 1 Tasikmadu, SMPN 3Karanganyar dan MTsN Karangmojo. Teknik pengumpulan data melalui metode angket, observasi, dan tes. Uji perbandingan untuk membandingkan nilai siswa pada kelas eksperimen yang menggunakan TTMC dan kelas kontrol yang menggunakan MCQ. Hasil penelitian menunjukkan : 1) langkah pengembangan TTMC telah melalui 9 tahapan Borg dan Gall. 2) Kelayakan TTMCdijamin melalui validitas isi dinilai baik oleh ahli,reliabilitas tinggi, memiliki tingkat kesukaran soal dengan proporsi $8 \%$ mudah, $64 \%$ sedang, dan $28 \%$ sulit, dan daya pembeda soal interpretasi rata-rata dinilai baik artinya layak digunakan dalam pembelajaran. 3) Respon guru belum pernah menggunakan soal dalam bentuk two-tier multiple choice question, lebih rumit dibandingkan pilihan ganda biasa, sudah bagus dan tertata rapi, guru bersedia menggunakan kembali soal pilihan ganda bertingkat dengan alasan bentuk soal ini menantang siswa untuk mengukur keterampilan proses sains. Profil siswa yang dikembangkan dapat memperlihatkan kemampuan keterampilan proses sains siswa dengan baik.
\end{abstract}

Kata kunci: Instrumen penilaian; Two-Tier Multiple Choice Question; Keterampilan Proses Sains

\section{Pendahuluan}

Hakikat IPA mencerminkan persoalan yang holistik dalam kehidupan nyata. IPA (Ilmu Pengetahuan Alam) dapat dikaji dari beberapa aspek yaitu sebagai bangunan ilmu (body of knowledge), cara berpikir (a way of thinking), cara penyelidikan ( $a$ way of investigation) dan kaitannya dengan teknologi dan masyarakat (Chiappetta \& Koballa, 2010). Dapat disarikan bahwa dalam IPA terdapat dimensi cara berpikir, cara investigasi, bangunan ilmu dan kaitannya dengan teknologi dan masyarakat. IPA terdiri atas dasar produk ilmiah, proses ilmiah, dan sikap ilmiah (Trianto, 2011). Hal ini menjadi substansi yang mendasar pentingnya pembelajaran IPA yang mengembangkan proses ilmiahnya untuk pembentukan pola pikir peserta didik.

IPA atau Sains memfokuskan pada pemberian pengalaman langsung dengan memanfaatkan dan menerapkan konsep, prinsip, fakta sains hasil temuan para 
ilmuan.Oleh karena itu peserta didik perlu dibantu untuk mengembangkan sejumlah keterampilan ilmiah untuk emmahami gejala/fenomena.Ipa merupakan mata pelajaran yang berupaya mengembangkan keterampilan peserta didika dalam menerapkan metode dan sikap ilmiah karena IPA identik dengan keterampilan proses yang menekankan pada pembeljaaran "bagaimana memperoleh suatu konsep" bukan pembelajaran "apa yang dimaksud dengan suatu konsep".

Keterampilan proses sains adalah sejumlah keterampilan untuk mengkaji fenomena alam dengan cara tertentu untuk memperoleh ilmu dan pengembangan ilmu (Patta, 2006). Akinbobola \& Afolabi (2010) menjelaskan bahwa keterampilan proses sains adalah keterampilan kognitif dan psikomotor yang digunakan dalam menyelesaikan masalah. Keterampilan proses sains adalah keterampilan yang ilmuwan gunakan dalam mengidentifikasi masalah, menyelidiki, mengumpulkan data, mentransformasi, mengintepretasi dan mengkomunikasikan. Oleh karena itu, penilaian keterampilan proses sains merupakan komponen penting dalam pembelajaran IPA.

Pengukuran keterampilan proses sains harus menggunakan penilaian yang jelas, valid, dan terkoordinasi sehingga hasilnya dapat digunakan untuk informasi di lapangan oleh guru dan siswa. Indikator keterampilan proses sains yang digunakan dalam penelitian pengembangan instrumen penilaian di adaptasi dari Semiawan (1992) meliputi mengamati, membuat hipotesis, eksperimen, mengendalikan variabel, menafsirkan data, menyusun kesimpulan, meramalkan, menerapkan, dan mengkomunikasikan.

Berdasarkan hasil angket yang dilakukan di forum MGMP guru SMP Karanganyar POKJA 5diperoleh data bahwa guru banyak yang menggunakan bentuk tes pilihan ganda pada mata pelajaran IPA. Penilaian yang dilakukan pun menggunakan soal tes yang cenderung tidak diuji validitas, reabilitas, tingkat kesukaran dan daya bedanya.

Selanjutnya, dilakukan wawancara dengan guru mata pelajaran.Dari hasil diskusi, ternyata penyebab ketidaktuntasan dikarenakan kurangnya latihan soal sebagai bagian dari evaluasi pembelajaran.Hal ini mengakibatkan kemampuan siswa kurang terasah dan berkembang. Penyebab lainnya adalah guru mata pelajaran hanya menggunakan dua teknik penilaian yaitu tes tertulisdan tanya jawab yang menyebabkan guru kurang mampu dalam mengetahui kemajuan dan kesulitan belajar siswa. Tampak bahwa sistem penilaian terhadap hasil belajar lebih banyak mengukur aspek kognitif berupa hapalan. Penilaian terhadap keterampilan proses sains belum dilakukan. Hal tersebut dikarenakan belum ada instrumennya. Hasil analisis kebutuhan di sekolah mendapatkan kesimpulan bahwa guru membutuhkan instrumen penilaian yang mampu mengukur keterampilan proses sains siswa.

Untuk mengukur keterampilan proses sains siswa dapat dilakukan dengan bentuk tes tertulis, lisan dan observasi. Keterampilan proses sains bukanlah keterampilan tangan dengan menggunakan alat-alat melainkan keterampilan proses berpikir dengan menggunakan prosesproses sains. Oleh karena itu pokok ujinyapun dapat berbentuk tes tertulis walaupun seringkali diperlukan alat untuk melengkapi pokok uji tersebut (Ariyati, 2009). Menurut Subali (2009), keterampilan proses sains termasuk keterampilan kognitif, sehingga penilaiannya dapat menggunakan tes tertulis. Salah satu bentuk tes tertulis adalah soal pilihan ganda (multiple choice). Soal pilihan ganda digunakan karena penilaian soal lebih objektif dan penskorannya mudah. Susilo (2013) mengembangkan instrumen tes keterampilan proses sains materi sistem pencernaan bentuk pilihan ganda dengan empat alternatif jawaban. Namun, bentuk tes ini mempunyai kelemahan yaitu kemungkinan siswa untuk menebak jawaban atau menjawab soal 
secara untung-untungan sangat besar. Soal pilihan ganda juga kurang mampu mengukur kemampuan kognitif yang lebih tinggi (Nofiana, 2013). Berdasarkan kelemahan tersebut, maka dipilih tipe penilaian modified multiple choice.

Salah satu alternatif modified multiple choice yang dapat digunakan untuk mengukur keterampilan proses sains siswa adalah bentuk two-tier multiple choice question (pilihan ganda bertingkat). Bentuk soal two-tier multiple choice question (TTMC)dikembangkan oleh Treagust (2006). Treagust menggunakan soal pilihan ganda bertingkat untuk mendiagnosis kemampuan siswa memahami konsep IPA. Nofiana (2013) menggunakan instrumen penilaianTTMC untuk mengukur keterampilan berpikir tingkat tinggi siswa. Bentuk soal terdiri dari dua tingkatan soal, tingkatan pertama merupakan isi soal yang memiliki dua alternatif jawaban dan tingkatan kedua merupakan alasan jawaban yang dipilih atas dasar pilihan pertama. Pengembangan instrumen penilaianTTMC dapat diterapkanuntuk mengukur keterampilan proses sains siswa dengan cara mengubah pola soal dan ada bagian yang perlu dikembangkan atau mengalami penyesuaian.

Materi mata sebagai alat optik dapat diajarkan secara terpadu dengan observasi dan eksperimen yang menuntut siswa untuk melakukan proses sains. Seharusnya siswa dapat menguasai materi tersebut dengan baik namun pada kenyataannya prolehan nilai pada materi ini masih terbilang rendah (Data UN tahun 2014 dan 2015). Oleh karena itu pembelajaran pada materi ini perlu dikembangkan lebih lanjut agar mencapai ketuntasan. Salah satu cara yang dapat dilakukan untuk mencapai ketuntasan pada materi ini adalah mengembangkan instrumen penilaian yang mampu melatih siswa untuk meningkatkan keterampilan proses sains. Penilaian pada materi ini memerlukan instrumen tes keterampilan proses sains sebagai alat ukur, sementara guru IPA belum memiliki tes yang mengukur keterampilan proses sains pada materi tersebut.

Berdasarkan latar belakang di atas, maka diperlukan penelitian pengembangan instrumen penilaian sebagai alat ukur keterampilan proses sains materi mata sebagai alat optik. Pengembangan instrumen penilaian digunakan untuk mengukur indikator keterampilan proses sains siswa. Instrumen penilaian hasil pengembangan diharapkan mampu memperbaiki kualitas alat penilaian siswa.

Adapun tujuan penelitian ini untuk : 1) Menggambarkan tahapan pengembangan instrumen penilaiantwo-tier multiple choice question. 2)Mengetahui kelayakan instrumen penilaiantwo-tier multiple choice question untuk mengukur keterampilan proses sains siswa SMA. 3) Mengetahui respon guru terhadap instrumen penilaiantwo-tier multiple choice question yang diterapkan di sekolah.

\section{Metode Penelitian}

Penelitian ini merupakan penelitian pengembangan (research and development $/ R$ $\& D$ ) yang bertujuan untuk mengembangkan instrumen penilaian bentuk two-tier multiple choice question yang digunakan untuk mengukur keterampilan proses sains siswa. Model yang digunakan sebagai dasar untuk pengembangan instrumen penilaian ini mengacu pada Borg and Gall (1983). Langkahnya adalah: 1) Melakukan penelitian pendahuluan dan pengumpulan informasi (research and information collecting). 2) Melakukan perencanaan (planning). 3) Mengembangkan bentuk produk awal (develop preliminary form of product). 4) Melakukan preliminary field testing. 5) Melakukan revisi terhadap produk utama (main product revision). 6) Melakukan main field testing, yaitu memvalidasi produk pengembangan dalam skala lebih luas serta dibandingkan dengan produk kontrol apabila memungkinkan. 7) Melakukan revisi terhadap produk operasional (operational product revision). 8) Melakukan operational field testing yaitu melakukan uji validasi 
terhadap produk operasional yang dihasilkan. 9) Melakukan revisi terhadap produk akhir (final product revision). 10) Mendeseminasikan dan mengimplementasikan produk (dissemination and implementation). Langkah pengembangan yang dilakukan pada penelitian sampai pada langkah ke sembilan karena untuk langkah ke sepuluh membutuhkan biaya yang mahal dan cakupan yang luas dalam waktu yang lama.

Responden pada penelitian ini adalah siswa kelas VIII SMPN 1 Tasikmadu, SMPN 3 Karanganyar dan MTsN Karangmojo serta guru IPA kelas VIII. Pada uji coba skala terbatas, produk diuji cobakan pada6 siswa dari ketiga sekolah. Pada uji coba skala menengah produk diuji cobakanpada 3 kelas dari ketiga sekolah. Pada uji coba skala luas produk diuji cobakan pada tiga kelas dari ketiga sekolah.

Teknik pengumpulan data dalam penelitian ini dengan metode angket, observasi, dan tes. Jenis data terdiri dari kualitatif dan kuantitatif. Teknik analisis data menggunakan statistik deskriptif persentase untuk jenis data kualitatif. Sedangkan jenis data kuantitatif yang diperoleh dari pengujian soal meliputi uji validitas, reliabilitas, daya beda, dan tingkat kesukaran soal menggunakan rumus masing-masing.

Pada tahap pengembangan draf I instrumen penilaian direvisi berdasarkan saran dari para ahli dan guru senior. Sebelum diuji cobakan instrumen penilaiandivalidasi oleh 4 orang ahli serta 5 orang guru senior. Kemudian dianalisis dengan teknik deskriptif persentase untuk memutuskan layaknya produk dilanjutkan tahap uji coba.

\section{Hasil Penelitian dan Pembahasan}

Tahap awal yang dilakukan yaitu pengumpulan informasi dilakukan di SMP.MTs Karanganyar yaitu 9 sekolah di Karanganyar, hal ini dilakukan karena uji lapangan di lakukan di 3 SMP/MTs di Karanganyar. $\begin{array}{llr}\begin{array}{l}\text { Pemilihan suatu } \\ \text { dikembangkan }\end{array} & \begin{array}{c}\text { produk } \\ \text { didasarkan }\end{array} & \text { yang } \\ \text { atas }\end{array}$ pengumpulan data kebutuhan yaitu berupa angket dan wawancara. Angket diberikan kepada 22 guru berupa angket terbuka.

Berdasarkan analisis kebutuhan guru diperoleh bahwa instrumen penilaian yang sering digunakan adalah bentuk pilihan ganda dan uraian disesuaikan dengan tipe materi. Guru mengatakan bahwa pada tipe soal pilihan ganda kurang bisa untuk mengukur pemahaman siswa sedangkan untuk soal uraian membutuhkan waktu lama untuk mengerjakannya dan memenuhi indikator pembelajaran yang ada. Guru telah mengukur hasil belajar kognitif, afektif, dan psikomotor. Guru menggunakan tes pilihan ganda dan uraian untuk pengukuran aspek kognitif. Guru menggunakan observasi untuk pengukuran aspek afektif. Guru tidak membuat rubrik penilaian psikomotor.

Materi yang dipilih adalah bertema Mata sebagai Alat Optik. Hal ini berdasarkan daya serap siswa SMPN 1 Tasikmadu, SMPN 3 Karanganyar dan MTsN Karangmojo pada materi Cahaya dan Alat Optik tergolong masih rendah dan guna memunculkan keterpaduan pelajaran IPA. Analisis ini di peroleh dari data hasil UN 2014 dan UN 2015. Untuk UN 2014 Ratarata nilai UN pada materi tersebut SMPN 1 Tasikmadu 69,31, SMPN 3 Karanganyar 59,57 dan MTsN Karangmojo 46,24 sedangkan Untuk UN 2015 Rata-rata nilai UN pada materi tersebut diperoleh SMPN 1 Tasikmadu sebesar 75,20, SMPN 3 Karanganyar sebesar 75,79 dan MTsN Karangmojo sebesar 43,02.

Materi dengan tema mata sebagai alat optik dapat membuat siswa untuk melakukan proses sains, dimana siswa dapat melakukan praktikum dengan menganalogikan alat-alat praktikum tersebuat sebagai bagian-bagian dari mata.oleh karena itu pembelajaran pada materi ini perlu dikembangkan lebih lanjut agar mencapai ketuntasan. Salah satu cara yang dapat dilakukan untuk mencapai ketuntasan pada materi ini adalah mengembangkan instrumen asesmen yang 
mampu melatih siswa untuk memberdayakan keterampilan proses sains. Penilaian pada materi ini memerlukan instrumen tes keterampilan proses sebagai alat ukur yaitu dalam bentuk Two-Tier Multiple Choice Question. (TMCQ)

Instrumen penilaian dibuat dalam bentuk pilihan ganda bertingkat yang biasa disebut two-tier multiple choice question terdapat soal utama dan alasan. Soal yang dibuat berbasis inkuiri dan keterampilan proses sains dimana soal berisi masalah yang dekat denagn kehidupan siswa sehingga dapat mengukur keterampilan proses sains yang dimiliki siswa.

Langkah yang dilakukan adalah sebagai berikut: merumuskan tujuan tes, merumuskan kawasan tes..menguraikan materi tes, menentukan kompetensi yang akan diuji, membuat kisi-kisi soal, mengembangkan produk awal pilihan ganda bertingkat dan penyusunan instrument validasi.

Bentuk soal two-tier multiple choice question merupakan alternatif soal pilihan ganda yang terdiri dari dua tingkatan soal. Bentuk soal ini diadaptasi dari Treagust (2006). Pemilihan bentuk soal two-tier multiple choice question sesuai dengan teori proses berpikir dari "John Dewey". John Dewey menyebutkan keterampilan berpikir tidak terjadi secara spontan tetapi harus ditimbulkan dengan "masalah dan pertanyaan". Implikasi teori Dewey tercermin dalam bentuk soal yang diberikan, soal tersebut mengandung masalah yang harus dipecahkan siswa melalui dua tahapan yakni dengan merespon jawaban "benar" atau "salah" serta dilanjutkan dengan memilih alasan dari pilihan tersebut. Soal two-tier multiple choice question bertujuan untuk merangsang siswa meningkatkan kemampuan berpikir yang tidak hanya sekedar menghapal.

Instrumen asesmen two-tier multiple choice question yang dikembangkan bertujuan untuk mengukur keterampilan proses sains. Teori yang melandasi keterampilan prorses sains adalah teori kognitif Bloom. Taksonomi Bloom merupakan dasar dari kerangka pemikiran kognitif yang merupakan aspek dari keterampilan proses sains.

Indikator keterampilan proses sains yang digunakan dalam penelitian pengembangan instrumen penilaian diadaptasi dari Semiawan (1992) meliputi mengamati, membuat hipotesis, eksperimen, mengendalikan variabel, menafsirkan data, menyusun kesimpulan, meramalkan, menerapkan, dan mengkomunikasikan. Implikasi teori kognitif Bloom dalam pengembangan instrumen asesmen terdapat pada indikator soal yang digunakan yang merupakan perpaduan antara indikator pembelajaran dan indikator keterampilan proses sains.

Instrumen penilaiantwo-tier multiple choiceselanjutnya di validasi oleh 4 para ahli dan 5 guru IPA SMP/MTs.Sebelum mendapatkan penilaian dari validator ahli(dosen) dan guru IPA, draft yang dikembangkan diberikan saran perbaikan sampai akhirnya diberikan penilaian. Validasi yang digunakan adalah validasi aiken dengan kriteria aiken sama dengan atau lebih dari 0.73 untuk tiap butir penilaiannya maka modul dikatakan valid dan dapat dilanjutan ketahap selanjutnya, indeks nilai 0,73 diperoleh dari banyaknya jumlah raters/validator yang memberikan penilaian terhadapinstrumen two-tier multiple choice. Data validasi ahli dan guru dianalisis, jika hasil validasi ahli dan guru belum layak maka dilakukan revisi terhadap produk sesuai saran ahli dan guru.

Hasil validasi diperoleh indeks validitas sebesar 0,891 yang berarti instrumen valid dan layak untuk digunakan.

Setelah melalui tahapan validasi dan dilakukan revisi pada intrumen two-tier multiple choice draf I maka didapatkan modul draf II, langkah selanjutnya adalah melakukan uji coba terbatas. Uji coba terbatas dilakukan di SMPN 1 Tasikmadu, SMPN 3 Surakarta dan MTsN Karangmojo dengan 1 guru dan 5 siswa di masing-masing sekolah yang digunakan dalam penelitian. Uji coba skala terbatas dilakukan guna 
mengetahui keterbacaan dari instrumen twotier multiple choice.

Tabel 1. Hasil Penilaian Instrumen TTMC oleh siswa pada Uji Coba Skala Terbatas

\begin{tabular}{|c|c|c|}
\hline No Aspek yang dinilai & Skor $(\%)$ & Kriteria \\
\hline 1. Susunan kalimat & 93,33 & Sangat $\mathrm{Ba}$ \\
\hline 2. Pemahaman soal & 80,00 & Sangat Baik \\
\hline 3. Istilah yang digunakan & 86,67 & Sangat Baik \\
\hline 4. Mengukur KPS & 93,33 & Sangat Bai \\
\hline 5. Waktu mengerjakan soal & 86,67 & Sangat Bai \\
\hline 6. Perintah mengerjakan soal & 100,00 & Sangat $\mathrm{Ba}$ \\
\hline Rata - rata & 90,00 & Sangat Baik \\
\hline
\end{tabular}

Uji coba skala menengah dilakukan pada 1 guru dan 1 kelas di masing-masing sekolah yang digunakan dalam penelitian. Siswa yang dilibatkan pada uji coba skala menengah diminta untuk mengerjakan soal kemudian hasilnya dianalisis untuk melihat reliabilitas, daya pembeda dan tingkat kesukaran dari butir soal yang dikembangkan.

A. Reliabilitas

Reliabilitas adalah ketetapan suatu alat penilaian.Kata "reliabilitas" sering diartikan sebagai keajegan atau kemantapan. Sebuah tes hasil belajar dapat dinyatakan reliabel jika hasil pengukuran yang dilakukan dengan menggunakan tes tersebut secara berulang kali terhadap subjek yang sama, senantiasa menunjukkan hasil yang tetap sama atau sifatnya ajeg dan stabil selama aspek yang diukur dalam diri subjek memang belum berubah. Tes atau alat penilaian dikatakan reliabel jika hasilnya dapat dipercaya, konsisten dan stabil.

Pengujian reliabilitas dilakukan dengan menggunakan program ITEMAN. Hasil pengujian reliabilitas instrumen penilaian keterampilan proses sains disajikan pada Tabel 2.

Tabel 2. Ringkasan Hasil Uji Reliabilitas Instrumen

\begin{tabular}{ccl}
\multicolumn{3}{c}{ Two Tier Test } \\
\hline Tier & Reliabilitas & Kriteria \\
\hline First & 0,753 & Tinggi \\
\hline Second & 0,871 & Tinggi \\
\hline
\end{tabular}

Uji reliabilitas instrumen penilaian pada ketiga SMP/MTs pada kedua Tier hasilnya > 0,7. Nilai ini menunjukkan bahwa instrumen tersebut memiliki reliabilitas tinggi, artinya soal tersebut memiliki kehandalan yang tinggi. Kehandalan yang dimaksud meliputi ketepatan atau kecermatan dalam pengukuran dan keajegan atau kestabilan dari hasil pengukuran.

B. Tingkat Kesukaran Soal

Tingkat kesukaran soal adalah peluang untuk menjawab benar suatu soal pada tingkat kemampuan tertentu yang biasanya dinyatakan dalam bentuk indeks. Tingkat kesukaran ini pada umumnya dinyatakan dalam bentuk proporsi yag besarnya berkisar 0,00-1,00. Semakin besar indeks tingkat kesukaran yang diperoleh dari hasil hitungan, berarti semakin mudah soal itu. Suatu soal memiliki $\mathrm{TK}=0$,00artinya bahwa tidak ada siswa yang menjawab benar dan bila memiliki $\mathrm{TK}=1,00$ artinya bahwa seluruh siswa menjawab benar. Perhitungan indeks tingkat kesukaran ini dilakukan untuk setiap nomor soal.

Klasifikasi tingkat kesukaran soal berdasarkan Depdiknas (2009) sebagai berikut:

$0,00-0,30=$ soal tergolong sukar

$0,31-0,70=$ soal tergolong sedang

$0,71-1,00=$ soal tergolong mudah

Hasil pengujian tingkat kesukaran instrumen penilaian keterampilan proses sains disajikan pada Tabel 3 dan Tabel 4.

Tabel 3. Ringkasan Hasil Uji Tingkat Kesukaran Instrumen Two Tier Test pada FirstTier

\begin{tabular}{lccc}
\hline Kategori & $\begin{array}{c}\text { Jumlah } \\
\text { Soal }\end{array}$ & $\begin{array}{c}\text { Nomor } \\
\text { Soal }\end{array}$ & $\begin{array}{c}\text { Persentase } \\
(\boldsymbol{\%})\end{array}$ \\
\hline Mudah & 2 & 23,25 & 8 \\
\hline Sedang & 16 & $1,2,3,4,7,8$, & 64 \\
& & $9,10,11,12$, & \\
& & $15,16,17,19$ & \\
& \multicolumn{3}{c}{20,22,} \\
\hline Sukar & 7 & $5,6,13,14,1$ & 28 \\
& & $8,21,24$ & \\
\hline
\end{tabular}

Tabel 4. Ringkasan Hasil Uji Tingkat Kesukaran Instrumen Two Tier Test pada SecondTier

\begin{tabular}{cccc}
\hline Kategori & $\begin{array}{c}\text { Jumlah } \\
\text { Soal }\end{array}$ & $\begin{array}{c}\text { Nomor } \\
\text { Soal }\end{array}$ & $\begin{array}{c}\text { Persentase } \\
(\%)\end{array}$ \\
\hline Mudah & 9 & $1,2,3,4,7$, & 36 \\
& & $14,15,24$, & \\
& & 25 & 64 \\
\hline Sedang & 16 & $5,6,8,9,1$ & \\
& & $0,11,12,1$ & \\
& & $3,16,17,1$ & \\
\hline
\end{tabular}




\begin{tabular}{cccc}
\hline Kategori & $\begin{array}{c}\text { Jumlah } \\
\text { Soal }\end{array}$ & $\begin{array}{c}\text { Nomor } \\
\text { Soal }\end{array}$ & $\begin{array}{c}\text { Persentase } \\
(\boldsymbol{\%})\end{array}$ \\
\hline & & $8,19,20,2$ \\
$1,22,23$ & \\
\hline Sukar & 0 & 0 & 0 \\
\hline
\end{tabular}

C. Daya Pembeda Soal

Daya pembeda soal adalah kemampuan sebuah instrumen penilaian untuk membedakan antara siswa yang telah menguasai materi dengan siswa yang tidak atau kurang atau belum menguasai materi yang ditanyakan.Kualifikasi daya pembeda berdasarkan Sudijono (2008) adalah sebagai berikut : Kurang dari 0,20 : jelek (J)

$\begin{array}{ll}0,20-0,40 & : \text { cukup (C) } \\ 0,41-0,70 & : \text { baik (B) } \\ 0,71-1,00 & : \text { baik sekali (BS) } \\ \text { Bertanda negatif } & \text { : jelek sekali (JS) }\end{array}$

Bertanda negatif : jelek sekali (JS)

Hasil daya pembeda instrumen penilaian keterampilan proses sains disajikan pada Tabel 5.dan Tabel 6.

Tabel 5.Ringkasan Hasil Uji Daya Pembeda Instrumen Two Tier Test pada First Tier

\begin{tabular}{cccc}
\hline Kategori & $\begin{array}{c}\text { Jumlah } \\
\text { Soal }\end{array}$ & $\begin{array}{c}\text { Nomor } \\
\text { Soal }\end{array}$ & Keterangan \\
\hline Baik & - & - & - \\
Sekali & & $1,4,7,9$, & Digunakan \\
\hline Baik & 10 & $12,14,1$ & \\
& & $5,16,17$ & \\
& & 25 & \\
\hline Cukup & 7 & $2,5,8,1$ & Digunakan \\
& & $8,19,21$ & \\
& &, 24 & \\
\hline Jelek & 6 & $3,6,10$, & Dibuang, \\
& & $11,13,2$ & Direvisi \\
& & 3 & \\
\hline Jelek & 2 & 20,22 & Dibuang \\
sekali & & & \\
\hline
\end{tabular}

Tabel 6. Ringkasan Hasil Uji Daya Pembeda Instrumen Two Tier Test pada Second Tier

\begin{tabular}{cccc}
\hline Kategori & $\begin{array}{l}\text { Jumlah } \\
\text { Soal }\end{array}$ & $\begin{array}{c}\text { Nomor } \\
\text { Soal }\end{array}$ & Keterangan \\
\hline Baik & 2 & 17,22 & Digunakan \\
Sekali & & & \\
\hline Baik & 15 & $5,6,9,1$ & Digunakan \\
& & $0,11,12$ & \\
& & \multicolumn{1}{c}{13,14,} & \\
& & $18,19,2$ & \\
& & 0,21, & \\
& & $23,24,2$ & \\
\hline Cukup & 7 & \multicolumn{1}{c}{5} & \\
& & $8,3,4,7,16$ & Digunakan \\
\hline Jelek & 1 & 2 & Direvisi \\
\hline Jelek & - & - & - \\
sekali & & & \\
\hline
\end{tabular}

Kriteria soal yang baik dapat dilihat dari validitas, reliabilitas, tingkat kesukaran dan daya pembeda soal. Berdasarkan hasil uji coba menengah dapat disimpulkan bahwa soal bernilai baik dengan reliabilitas yang tinggi dan berkategori sedang. Berdasarkan hasil ITEMAN dari soal utama dan alasan terdapat 5 soal yang direduksi yaitu soal dengan nomor $3,6,13,20,22$. Pemilihan reduksi soal 5 nomor tersebut didasarkan pada daya pembeda yang jelek. Untuk soal no 2 walaupun memiliki daya pembeda yang jelek pada alasan soal direvisi karena ketercapaian indikator yang harus dipenuhi.

Setelah dilakukan uji coba skala terbatas dan uji coba skala menengah, selanjutnya dilakukan uji coba skala luas. Uji coba skala luas dilakukan dengan mengujicobakan instrumen TTMC di tiga kelas. Pada uji coba skala luas, dilakukan pretest dan postest dengan soal two tier multiple choice yang telah dikembangkan.

pelaksanaannya harus mendekati operasional sekolah. Menurut Borg dan Gall (1983), tujuan uji coba operasional ini adalah menentukan apakah produk pendidikan siap digunakan di sekolah tanpa kehadiran pengembang. Agar siap digunakan secara operasional, paket produk harus lengkap dan diuji secara keseluruhan dalam setiap hal. Borg dan Gall (1983) masih mengadakan penyempurnaan pada tahap ini. Menurut Sukmadinata (2006), pengujian produk akhir ini bertujuan untuk mengetahui kelayakan produk dan keunggulan dalam praktek. Pada pengujian ini, tidak dilakukan untuk menyempurnakan produk karena produk sudah dipandang sempurna pada uji coba lapangan. Data yang diperoleh pada tahap uji coba operasional (penilaian, komentar, hasil pengamatan dan saran siswa) disusun dan dianalisis untuk merevisi produk sehingga menjadi produk akhir.

Respon siswa terhadap instrumen asesmen two-tier multiple choice question didapat dari uji perbandingan menggunakan uji beda rerata antara instrumen asesmen two- tier multiple choice question dengan 
instrumen asesmen multiple choice question. Pengujian dilakukan pada 68 orang siswa dari SMAN 1 Surakarta yang terdiri dari 2 kelas dan 64 orang siswa dari SMAN 2 Surakarta yang terdiri dari 2 kelas.

Soal two-tier multiple choiceyang dikembangkan selain berfungsi sebagai alat penilaian juga berfungsi sebagai alat penilaian untuk mengukur keterampilan proses sains. Dimana soal dikembangkan berdasarkan indikator keterampilan proses sains. Hasil skor siswa kemudian dibagi berdasarkan jenjang kategori keterampilan proses sains yaitu kategori tinggi (skor 4160), sedang (skor 21-40) dan rendah (skor 0-20). Berdasarkan skala kategori keterampilan proses sains maka hasil pengelompokan siswa dapat dilihat pada diagram berikut.

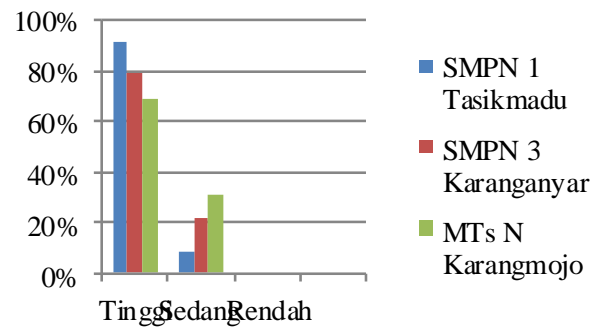

Gambar 1. Hasil Keterampilan Proses Sains Siswa

Respon guru terhadap instrumen asesmen hasil pengembangan diperoleh dari hasil angket dan wawancara. Hasilnya antara lain guru belum pernah menggunakan soal dalam bentuk two-tier multiple choice question (pilihan ganda bertingkat), soal dalam bentuk pilihan ganda bertingkat lebih rumit dibandingkan dengan pilihan ganda biasa, bentuk soal sudah bagus dan tertata rapi, bentuk soal ini lebih menantang kemampuan berpikir siswa, soal ini cocok untuk melihat kemampuan berpikir siswa sampai sejauh mana, soal ini cocok digunakan untuk melihat efektivitas pembelajaran yang dilakukan guru serta pemahaman konsep pada siswa terhadap materi yang diajarkan.

Hasil angket menunjukkan bahwa tidak semua guru bersedia menggunakan kembali soal pilihan ganda bertingkat untuk mengukur pemahaman siswa pada materi asam basa. Bentuk soal ini dinilai lebih cocok sebagai soal diagnosis keterampilan berpikir dan tidak relevan untuk pengambilan nilai. Namun guru yang lain bersedia menggunakan kembali soal pilihan ganda bertingkat dengan alasan bentuk soal ini menantang siswa untuk meningkatkan keterampilan proses sains yang tidak hanya sekedar hapalan, dapat digunakan sebagai soal ulangan harian karena dapat fokus untuk materi ini saja dan soal termasuk jenis sederhana tetapi siswa harus benarbenar memahami konsep materinya, dan juga mampu menghindari siswa untuk menebak jawaban seperti jika mengerjakan soal pilihan ganda biasa karena adanya tingkatan soal yaitu pokok soal dan alasan jawaban yang saling terkait.

Respon guru terhadap instrumen asesmen hasil pengembangan sesuai dengan penelitian Sampson (2006) yang menyebutkan keuntungan penggunaan twotier multiple choice question bagi guru adalah sebagai wawasan membuat bentuk penilaian yang menantang pengetahuan siswa serta menyediakan cara untuk menilai pemahaman konsep siswa. Penelitian dari Treagust (1995) menyebutkan bentuk twotier multiple choice question lebih efektif untuk menentukan alternatif konsep materi pada siswa dan dan untuk melihat apakah suatu pembelajaran bermakna atau tidak.

Keterampilan proses sains merupakan tuntutan dari Standar Isi dan Standar Kompetensi Lulusan sekolah menengah. Apabila siswa sering dilatihkan menggunakan instrumen asesmen two-tier multiple choice question yang memberdayakan keterampilan proses sains maka diharapkan hasil belajar dan keterampilan proses sains siswa meningkat.

\section{Kesimpulan dan Rekomendasi}

\section{Kesimpulan}

Berdasarkan hasil analisis data dan pembahasan yang telah dilakukan dapat disimpulkan: 
1. Langkah pengembangan TTMC telah melalui 9 tahapan Borg dan GallKarakteristik instrumen asesmen two-tier multiple choice question yang mengukur keterampilan proses sains. Indikator keterampilan proses sains yang digunakan dalam penelitian pengembangan instrumen penilaian diadaptasi dari Semiawan (1992) meliputi mengamati, membuat hipotesis, eksperimen, mengendalikanvari abel, menafsirkan data, menyusun kesimpulan, meramalkan, menerapkan, dan mengkomunikasikan. serta memiliki validitas yang baik dan reliabilitas yang tinggi.

2. Kelayakan TTMCdijamin melalui validitas isi dinilai baik oleh ahli,reliabilitas tinggi, memiliki tingkat kesukaran soal dengan proporsi $8 \%$ mudah, $64 \%$ sedang, dan $28 \%$ sulit, dan daya pembeda soal interpretasi rata-rata dinilai baik artinya layak digunakan dalam pembelajaran.

3. Respon guru terhadap penerapan instrumen asesmen two-tier multiple choice question didapatkan melalui hasil angket dan wawancara. Hasilnya antara lain guru belum pernah menggunakan soal dalam bentuk two-tier multiple choice question, soal dalam bentuk pilihan ganda bertingkat lebih rumit dibandingkan dengan pilihan ganda biasa,bentuk soal ini lebih menantang kemampuan berpikir siswa, soal ini cocok digunakan untuk melihat pemahaman siswa dalam terhadap materi yang diajarkan. Hasil angket menunjukkan bahwa guru yang bersedia menggunakan kembali soal pilihan ganda bertingkat dengan alasan bentuk soal ini menantang siswa untuk meningkatkan keterampilan proses sains yang tidak hanya sekedar hapalan, dapat digunakan sebagai soal ulangan harian karena dapat fokus untuk materi ini saja dan juga mampu menghindari siswa untuk menebak jawaban seperti jika mengerjakan soal pilihan ganda biasa karena adanya tingkatan soal yaitu pokok soal dan alasan jawaban yang saling terkait.

\section{Rekomendasi}

Saran sebelum menggunakan instrumen asesmen hasil pengembangan ini adalah :

1. Guru sebaiknya mengajarkan materi mata sebagai alat optikmenggunakan model pembelajaran yang telah memberdayakan keterampilan proses sains.

2. Penggunaan produk TTMC yang digunakan untuk meningkatkan Keterampilan Proses Sains siswa harus mempertimbangkan waktu yang digunakan.

3. Penilaian yang terkait dengan model pembelajaran yang memberdayakan keterampilan proses sains siswa masih perlu dikembangkan dan diteliti lebih lanjut.

4. Penelitian yang terkait dengan bentuk soal two-tier multiple choice question masih perlu dikembangkan dan diteliti lebih lanjut.

\section{Daftar Pustaka}

Akinbobola, A.O., and Afolabi, F. (2010). Analysis of science process skills inWest African senior secondary school certificate physics practical examinations in Nigeria. AmericanEurasian Journal of ScientificResearch, 5 ( 4), pp 234-240

Ariyati, E. 2009. Keterampilan Proses Sains. Program Studi Ilmu Pengetahuan Alam Konsentrasi Pendidikan Biologi-SL. Sekolah Pasca Sarjana. Universitas Pendidikan Indonesia. Makalah. Tidak diterbitkan.

Borg, W.R dan Gall, M.D. 1983. Educational Research An Introduction (4th Ed). White Plains : Logman Inc.

Chiappetta, E. L., and Koballa, T. R. (2010). Science instruction in the middle andsecondary schools (7th ed). New York:Pearson Education

Nofiana, M. 2013. Pengembangan Instrumen Evaluasi Two-Tier Multiple Choice 
Question untuk Mengukur Keterampilan Berpikir Tingkat Tinggi pada Materi Kingdom Plantae. Pascasarjana. Universitas Sebelas Maret. Tesis. Tidak diterbitkan.

Patta, Bundu. (2006). Penilaian keterampialn proses dan sikap ilmiah dalam pembelajaran sains SD. Jakarta:Depdiknas.

Sampson, V. 2006. Two-Tier Assessment. Teacher Toolkit. Arizona : College of Education At Arizona State University In Tempe.

Semiawan, C., 1992, Pendekatan Keterampilan Proses, Jakarta : PT. Gramedia.

Subali, B. 2009. Pengembangan Tes Pengukur Keterampilan Proses Sains Pola Divergen Biologi SMA. Makalah disajikan pada Prosiding Seminar Nasional Biologi, Lingkungan dan Pembelajarannya. Jurdik Biologi, FMIPA, Universitas Negeri Yogyakarta,4 Juli 2009

Sukmadinata, N.S. 2006. Metode Penelitian Pendidikan. Bandung : PT Remaja Rosdakarya

Susilo, H. 2013. Pengembangan Tes Keterampilan Proses Sains Materi Sistem Pencernaan Kelas XI SMA N 1 Pemalang. Skripsi.

Treagust, D.F. 2006. Development and Use of Diagnostic Test to Evaluate Students Misconception In Science. International Journal of Science Education, 10, 2 pp 159-169.

Trianto. (2012). Model Pembelajaran Terpadu: Konsep, Strategi, dan Implementasinya dalam Kurikulum Tingkat Satuan Pendidikan. Jakarta: Bumi Aksara. 